
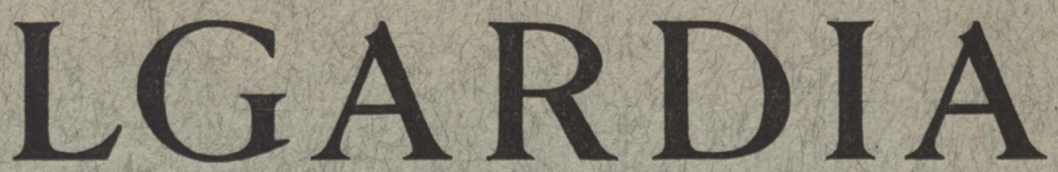

A Journal of Agricultural Science Publisbed by the California Agricultural Experiment Station

CONTENTS

NEWLY DISCOVERED LEAFHOPPER

VECTORS OF CALIFORNIA

ASTER-YELLOWS VIRUS

HENRY H. P. SEVERIN

CHARACTERS, DISTRIBUTION, AND FOOD PLANTS OF NEWLY DISCOVERED VECTORS OF CALIFORNIA ASTER-YELLOWS VIRUS DWIGHT M. DELONG AND HENRY H. P. SEVERIN

LONGEVITY OF NONINFECTIVE AND INFECTIVE LEAFHOPPERS ON A PLANT NONSUSCEPTIBLE TO A VIRUS HENRY H. P. SEVERIN 
LONGEVITY OF NONINFECTIVE AND INFECTIVE LEAFHOPPERS ON A PLANT NONSUSCEPTIBLE TO A VIRUS

HENRY H. P. SEVERIN 



\section{LONGEVITY OF NONINFECTIVE AND INFECTIVE LEAFHOPPERS ON A PLANT NONSUSCEPTIBLE TO A VIRUS ${ }^{1}$}

HENRY H. P. SEVERIN ${ }^{2}$

\section{INTRODUCTION}

IN A recent paper (Severin, 1946), ${ }^{3}$ evidence was presented that nine species of leafhopper vectors tested, completed the nymphal stages on celery or asters infected with the California aster-yellows virus, but died when transferred to healthy celery or asters. Conceivably, this might be either (1) because the virus itself is beneficial to the vector, or (2) because the host plant is modified by virus infection to become a more favorable food and breeding plant for the vector. This paper deals with the first possibility, through a comparative study of the longevity of noninfective and infective leafhoppers on a host plant nonsusceptible to the virus. If the virus is beneficial to the vectors, it is reasonable to assume that the adult life of infective leafhoppers reared during the nymphal stages on infected host plants would be longer on a host plant nonsusceptible to the virus, than that of noninfective adults kept on the same species of nonsusceptible host plant. On the other hand, if the virus is injurious to the vectors, then the longevity of infective leafhoppers would be shorter than that of noninfective adults kept on the same species of nonsusceptible host plant.

It is not the purpose of this paper to enter into a discussion as to whether the plant has been modified by virus infection to become a more favorable host plant for the vector.

\section{METHODS}

Short-winged and long-winged aster leafhoppers were used. The latter is a biological race of the same species, Macrosteles divisus Uhl. The noninfective insects were reared on mildew-resistant Sacramento barley, which is nonsusceptible to the virus. Infective leafhoppers were reared on diseased China asters (Callistephus chinensis) and plantain, or ribgrass (Plantago major).

In January, soon after the last molt, lots of 50 or 100 noninfective and infective male or female leafhoppers were confined in cages enclosing Sacramento barley. Each month the leafhoppers were transferred to thrifty growing barley plants, and a record was taken of the mortality.

\section{RESULTS}

Table 1 gives the results obtained. As shown in this table, no mortality of noninfective or infective adults of either vector occurred during the first month. An examination of the mortality records in the first test of the short-

\footnotetext{
${ }^{1}$ Received for publication November 4, 1946.

2 Entomologist in the Experiment Station.

${ }^{3}$ See "Literature Cited" for citations, referred to in the text by author and date.
} 
winged aster leafhoppers during the next four months shows a higher death rate of noninfective than of infective males, but the reverse is true when the data for the second test are compared.

TABLE 1

Monthly Mortality of Noninfective and Infective Adult Short-winged and Longwinged Macrosteles divisus on Sacramento Barlet, Nonsusceptible to Aster-Yellows Virus

\begin{tabular}{|c|c|c|c|c|c|c|c|}
\hline \multirow{2}{*}{$\begin{array}{l}\text { Sex and } \\
\text { condition of } \\
\text { aster leafhopper, } \\
\text { and test no. }\end{array}$} & \multirow{2}{*}{$\begin{array}{l}\text { Adults } \\
\text { in } \\
\text { each lot }\end{array}$} & \multicolumn{6}{|c|}{$\begin{array}{l}\text { Cumulative mortality, per cent } \\
\text { (Leafhoppers transferred to barley in January) }\end{array}$} \\
\hline & & Feb. & Mar. & Apr. & May & June & July \\
\hline 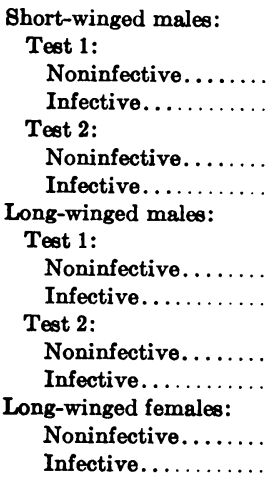 & $\begin{array}{l}50 \\
50 \\
\\
50 \\
50 \\
\\
50 \\
50\end{array}$ & $\begin{array}{l}0 \\
0 \\
0 \\
0 \\
0 \\
0\end{array}$ & $\begin{array}{l}18 \\
32 \\
\\
28 \\
30 \\
\\
24 \\
18\end{array}$ & $\begin{array}{l}48 \\
72 \\
54 \\
62\end{array}$ & $\begin{array}{l}94 \\
88 \\
\\
86 \\
88\end{array}$ & $\begin{array}{r}100 \\
100 \\
98 \\
98 \\
\\
98 \\
100\end{array}$ & $\begin{array}{c}\cdots \\
\cdots \\
100 \\
100 \\
\\
100 \\
\cdots\end{array}$ \\
\hline
\end{tabular}

With both tests of long-winged aster leafhoppers, table 1 shows a higher mortality of infective than of noninfective adults, both male and female. The slight difference is not significant.

\section{CONCLUSION}

The results indicate that the virus itself is neither beneficial nor injurious to infective short-winged and long-winged adult aster leafhoppers, Macrosteles divisus, as determined by a comparison of the monthly death rate of noninfective and infective adults kept on a host plant nonsusceptible to the California aster-yellows virus. 


\section{LITERATURE CITED}

Severin, H. H. P.

1940. Potato naturally infected with California aster-yellows. Phytopathology 30(12): 1049-51.

1946. Longevity, or life histories, of leafhopper species on virus-infected and on healthy plants. Hilgardia 17(3):121-37. 

